\title{
Penerapan Pembelajaran Authentic Instruction Learning dalam Upaya Meningkatkan Pemahaman PKn Siswa
}

\author{
Hafsah $^{1}$, Nursani ${ }^{2}$ \\ ${ }^{1}$ Pendidikan Pancasila dan Kewarganegaraan, Universitas Muhammadiyah Mataram, Email: dansa_machi@yahoo.co.id \\ ${ }^{2}$ Pendidikan Pancasila dan Kewarganegaraan, Universitas Muhammadiyah Mataram, Email: nursani093@gmail.com
}

\begin{tabular}{|c|c|}
\hline INFO ARTIKEL & ABSTRAK \\
\hline Riwayat Artikel: & \multirow{8}{*}{$\begin{array}{l}\text { Abstrak: Dalam pembentukan sumber daya manusia (SDM) yang berkualitas itu, peranan } \\
\text { pendidikan kewarganegaraan khususnya meningkatkan pemahaman PKn sangat penting, } \\
\text { terutama pada jenjang pendidikan menengah. Dapat meningkatkan pemahaman PKn harus } \\
\text { memuat empat komponen yang sangat mendasar dalam membaca antara lain mencatat, } \\
\text { tugas, observasi, dan presentasi. Tujuan penelitian untuk menjelaskan penerapan } \\
\text { pembelajaran authentic instruction learning dalam upaya meningkatkan pemahaman PKn } \\
\text { siswa. Metode penelitian ini menggunakan Penelitian ini menggunakan rancangan } \\
\text { classroom action research, subyek penelitian sebanyak } 38 \text { orang. Pengumpulan data } \\
\text { menggunakan observasi dan tes, analisis data menggunakan rumus ketuntasan belajar. Hasil } \\
\text { penelitian menunjukkan penerapan pembelajaran Authentic Intruction Learning mampu } \\
\text { meningkatkan pemahaman belajar siswa pada mata pelajaran Pendidikan Kewarganegaraan. } \\
\text { Hal ini terlihat pada siklus I nilai rata-rata dari } 38 \text { siswa adalah } 65,52 \text { dengan persentase } \\
\text { ketuntasan belajar adalah } 57,89 \% \text {, kemudian pada siklus II nilai rata-rata dari } 38 \text { siswa adalah } \\
72.36 \text { dengan persentase ketuntasan belajarnya adalah } 78,94 \% \text {, kemudian pada siklus III } \\
\text { diperoleh nilai rata-rata dari } 38 \text { siswa adalah } 84,47 \text { dengan presentase ketuntasan belajar } \\
\text { adalah } 100 \% \text {. Jadi pembelajaran Authentic Instruction Learning disamping mammpu } \\
\text { meningkatkan pemahaman konsep PKn, dapat juga meningkatkan sikap kerjasama tim } \\
\text { dalam berdiskusi dalam proses pembelajaran. }\end{array}$} \\
\hline Diterima: 18-Maret-2020 & \\
\hline Disetujui: 29-Maret-2020 & \\
\hline & \\
\hline Pembelajaran & \\
\hline $\begin{array}{l}\text { Authentic } \\
\text { Learning }\end{array}$ & \\
\hline Meningkatkan & \\
\hline Pemahaman & \\
\hline
\end{tabular}

\begin{abstract}
In the establishment of qualified human resources, the role of citizenship education, in particular, enhances the understanding of Civic Education is very important, especially in the secondary education level. Can increase the knowledge of Civic Education should contain four fundamental components in reading, among others, taking notes, tasks, observations, and presentations. The purpose of research to explain the implementation of learning authentic instruction learning to improve the understanding of Civic Education students. This research method uses the research using classroom action research, subject to research as much as 38 people: data collection using observations and tests, data analysis using learning-submission formulas. Instruction Learning was able to improve students learning understanding of citizenship education subjects. This was seen on the / cycle. The average value of 38 students is 65.52 , with the percentage of learning submission is $57.89 \%$. In cycle II the average cost of 38 students is 72.36, with the interest of the study's presentation is $78.94 \%$. The III cycle obtained an average value of 38 students is 84.47 , with a percentage of the learning is $100 \%$. So the teaching of Authentic Instruction Learning, in addition to improving the understanding of the concept of Civic Education, can also increase the attitude of teamwork in the discussion in the learning process.
\end{abstract}

\section{A. LATAR BELAKANG}

Dalam pembentukan sumber daya manusia (SDM) yang berkualitas itu, peranan pendidikan kewarganegaraan khususnya meningkatkan pemahaman PKn sangat penting, terutama pada jenjang pendidikan menengah. Dapat meningkatkan pemahaman PKn harus memuat empat komponen yang sangat mendasar dalam membaca antara lain mencatat, tugas, observasi, dan presentasi. Apabila keempat komponen tersebut telah mantap / dikuasai maka pembelajaran PKn ketingkat yang lebih tinggi tidak terlalu sulit.

Penelitian ini dilatar belakangi beberapa penelitian terdahulu, Newmann and Wehlage menemukan dalam Authentic Teaching and Learning dapat mengarahkan berpikir struktur siswa untuk meraih substansi, inovasi dan prestasi belajar, pembelajaran ini dilakukan dalam kelas [1]. Peneliti lain telah mempertimbangkan siswa dapat mengekplorasi konsep authenticity dengan menggunakan pendekatan AI [2];[3];[4];[5]. Sementara Nikitina menemukan authentic learning ini dapat 
mengoservasi bahasa asli yang dilakukan peserta didik melalui proyek video, implementasinya berhasil dengan diterapkan berbagai mata pelajaran pada setiap kelas [6]. Sementara di Indoensia penerapan authenticy learning mampu meningkatkan prestasi belajar siswa sekolah dasar [7]. Secara keseluruhan temuan mereka ada kesamaan pada aspek authentic learning, prestasi belajar, dan aktivitas belajar. Sementara perbedaannya pada aspek metode penelitian, subyek penelitian, lokasi penelitian, dan variable penelitian. Dengan demikian authentic learning perlu dikembangkan lagi agar menghasilkan berbagai ragam penelitian. Hal inilah untuk diujicobakan atau diukur kembali dalam penelitian ini adalah mengukur kemampuan pemahaman konsep pendidikan kewarganegaraan (PKn) siswa dengan menerapkan pembelajaran Authentic Instruction Learning pada siswa sekolah menengah pertama.

Berdasarkan observasi bahwa kemampuan pemahaman konsep pendidikan kewarganegaraan siswa cukup beragam ada yang rendah dan yang tinggi. Hasil capaian KKM hanya mencapai 70 sementara KKM standarnya minimal 75 , artinya ada masalah pada guru dan siswa. Jika kondisi tersebut dibiarkan, maka dikhawatirkan akan berdampak secara sistematis baik bagi siswa, guru, dan sekolah. Bagi sekolah mengakibatkan suasana belajar menjadi kurang hidup, siswa lebih senang berbicara dengan temannya daripada mencatat atau memperhatikan penjelasan dari guru. Siswa terkesan kurang senang pada mata pelajaran khususnya mata pelajaran $\mathrm{PKn}$, sehingga berdampak pada prestasi siswa itu sendiri. Akibatnya guru mengalami kesulitan untuk menentukan apakah siswa sudah memahami atau tidak materi yang disampaikan oleh guru, selain itu guru harus lebih kreatif dan inofatif dalm pembelajaran. Sedangkan bagi sekolah, tentunya akan sulit untuk bersaing dengan sekolah-sekolah lain dikarenakan mutu dan kualitas masih dibawa standard.

Pemilihan model, metode maupun media pembelajaran yang tepat dapat meningkatkan partisipasi dan kreaktifan siswa dalam proses belajar mengajar akan meningkat. Hal tersebut akhirnya juga berpengaruh terhadap hasil belajar sebab dengan proses belajar mengajar yang konduksif siswa diharapkan akan mudah menyerap materi pelajaran dan secara tidak langsung akan berpengaruh pada hasil belajarnya. Untuk itu, cara mengatasi kondisi kemampuan pemahaman siswa tersebut, dapat dipergunakan pembelajaran Authentic Instruction Learning sebagai upaya meningkatkan pemahaman PKn siswa. Burikut diurikan pembuktian pembelajaran tersebut.

Authentic Intruction Learning berfokus pada tujuan, melibatkan pembelajaran secara langsung, mengharuskan membangun keterkaitan dan kerja sama, dan menanamkan tingkat berpikir yang lebih tinggi [8]. Para siswa dapat menunjukkan penguasaannya terhadap tujuan pelajaran dan kedalaman pemahamannya, dan pada saat bersamaan meningkatkan pengetahuan dan menemukan cara untuk memperbaiki diri. Authentic Intruction Learning merupakan pendekatan pengajaran yang memperkenalkan siswa untuk mempelajari konteks yang bermakna melalui pengembangan keterampilan berfikir dan pemecahan masalah yang penting didalam kehidupan nyata[9].

Authentic Learning dapat membantu siswa menyadari akan relevasi dan kebermaknaan apa yang telah mereka pelajari karena mempelajari konteks yang nyata [10]. Pembelajaran yang bermakna membuat pembelajaran menjadi lebih menyenangkan. Hal ini sejalan dengan pendapat Hiang, bahwa pembelajaran autentik membuat pembelajaran menjadi lebih menyenangkan, relevan dan efektif [11]. Hal ini dibuktikan dengan penelitian yang dilakukan oleh Bormann[12] hasilnya menunjukkan bahwa pembelajaran menggunakan authentic learning dapat meningkatkan penguasaan konsep siswa siswa yaitu siswa dengan IPK yang baik skor rata-rata 71,29\% (berkisar dari 61,45 ke 82,06). Kebanyakan siswa memiliki nilai yang tinggi dan sedang (masing-masing $54,20 \%$ dan 41,30\%). Demikian pula lainnya [13] menemukan bahwa aPBL berpengaruh terhadap penguasaan konsep pembelajaran siswa karena adanya langkah-langkah pada pembelajaran aPBL yang membuat siswa lebih menguasai konsep yang dipelajari di antaranya melalui penyelesaian masalah yang berkaitan dengan kejadian sehari-hari dan membuat ringkasan dan pengetahuan abstrak (flowchart).

Berdasarkan permasalahan, kelemahan tersebut, maka perlu adanya upaya guru untuk meningkatkan pemahaman siswa dengan memilih metode yang tepat dengan model pembelajaran/pendekatan berbasis masalah. Maka hipotesis menyatakan bahwa terdapat peningkatan signifikan pemahaman PKn siswa setelah penerapan pembelajaran authentic intruction learning. Tujuan yang diharapkan pada artikel ini adalah menjelaskan penerapan pembelajaran authentic intruction learning dalam upaya meningkatkan pemahaman PKn siswa.

\section{B. METODE PENELITIAN}

1. Metode yang digunakan

Penelitian ini menggunakan rancangan classroom action research atau penelitian tindakan kelas yang didalamnya terbentuk dari rangkaian siklus kegiatan, karena didasarkan pada masalah yang dihadapi oleh guru didalam kelas diantaranya aktivitas siswa dan pemahaman, serta bertujuan untuk memperbaiki dan meningkatkan kualitas instruksional.

2. Metode penentuan subjek

Subyek dalam penelitian ini adalah seluruh siswa kelas VIII4 di SMP Negeri 1 Hu'u Kecamatan Hu'u yang 38 orang yang berdiri dari 15 orang siswa laki-laki dan 
23 orang siswa perempuan yang ada di SMP Negeri 1 Hu'u.

\section{Metode Pengumpulan Data}

1. Observasi

observasi dilakukan untuk penyelidikan dan mengumpulkan data dengan menggunakan alat indra, baik lansung maupun tidak lansung terhadap fakta-fakta pembelajaran dan pemahaman siswa.

\section{Tes}

Tes ini berfungsi untuk melihat tingkat pemahaman siswa terhadap proses pembelajaran yang tercermin dalam prestasi belajar siswa dilakukan dengan tes yang berupa soal-soal untuk berorientasi pemahaman berupa test obyektif.

\section{Instrumen penelitian}

Instrumen penelitian yang digunakan yaitu 25 soal dengan soal pilihan ganda 20 soal dan essay 5 soal. Hasil validitas soal atau kesukaran soal adalah valid, reliabilitas soal layak diterapkan.

\section{Analisis Data}

Setelah memperoleh data tes hasil belajar siswa maka data tersebut dianalisis dengan mencari ketuntasan belajar kemudian dianalisis secara kuantitatif untuk mengetahui ketuntasan belajar siswa digunakan kriteria sebagai berikut:

a. Ketuntasan individu setiap siswa dalam proses belajar mengajar dikatakan tuntas secara individu apabila siswa mampu memperoleh nilai $\geq 65$, sebagai standar ketuntasan minimal yang ditetapkan oleh sekolah tempat peneliti melakukan penelitian dan melakukan konversi dengan rumus sebagai berikut:

Rumus ketuntasan individu yaitu :

$N=\frac{T}{T t} x 100 \%$

Keterangan :

$\mathrm{N}=$ ketuntasan belajar siswa (proporsi jawaban yang benar )

$\mathrm{T}=$ Nilai yang di capai siswa

$\mathrm{Tt}=$ Jumlah skor maksimal [14]

b. Ketuntasan klasikal dapat dihitung dengan persamaan sebagai berikut [15].

$$
\mathrm{KK}=\underline{\mathrm{X}} \times 100 \%
$$

\section{$\mathrm{Z}$}

Keterangan :

$\mathrm{KK}=$ Ketuntasan belajar

$\mathrm{X}=$ Jumlah siswa yang memperoleh $\geq 65$

$\mathrm{Z}$ = Jumlah siswa yang ikut tes

Sesuai dengan tehnik penelitian, kelas dapat dikatakan tuntas secara klasikal apabila ketuntasan klasikal mencapai 85\% dari siswa yang memperoleh nilai $\geq 65$.

\section{HASIL DAN PEMBAHASAN}

\section{Deskripsi Proses dan Hasil Penelitian}

Hasil penelitian tindakan kelas memberikan gambaran tentang kegiatan siswa selama proses belajar berlangsung dan data kuantitatif yaitu data tentang kegiatan siswa selama proses belajar berlangsung dan data kuantitatif yaitu data tentang hasil belajar siswa. Pada tahap pelaksanaan dalam penelitian tindakan kelas ini dilakukan sebanyak tiga siklus dengan tindakan berulang-ulang dan masing-masing siklus terdiri dari 4 kali pertemuan.

Adapun tahapan dalam pembelajaran pembelajaran authentic intruction learning dalam upaya meningkatkan pemahaman PKn siswa [14], yaitu:

1) pengajuan pertanyaan atau masalah

2) berfokus pada keterkaitan antar disiplin

3) penyelidikan autentik. Pembelajaran berdasarkan masalah mengharuskan siswa melakukan penyelidikan autentik untuk mencari penyelesaian nyata terhadap masalah nyata. Mereka harus menganalisis dan mendefinisikan masalah, mengembangkan hipotesis, dan membuat ramalan, mengumpul dan menganalisa informasi, melakukan eksperimen (jika diperlukan), membuat inferensi, dan merumuskan kesimpulan.

4) menghasilkan produk dan memamerkannya.

5) kolaborasi. Pembelajaran berdasarkan masalah dicirikan oleh siswa yang bekerja sama satu dengan yang lainnya, paling sering secara berpasangan atau dalam kelompok kecil. Bekerja sama memberikan motivasi untuk secara berkelanjutan terlibat dalam tugas-tugas kompleks dan memperbanyak peluang untuk berbagi inkuiri dan dialog dan untuk mengembangkan keterampilan sosial dan ketrampilan berpikir

Tabel 1

Pembelajaran Authentic Intruction Learning Dalam Upaya Meningkatkan Pemahaman PKn Siswa setiap siklus 
Siklus I

Siklus II

Tahap perencanaan:

- Menyiapkan bahan ajar.

- Menyiapkan

Perencanaan

Pembelajaran

(RPP) yang

berdasarkan

pembelajaran kontekstual dengan pendekatan Authentic intruction learning.

- Menyiapkan lembar observasi siswa

- Menyiapkan soal tes beserta jawaban untuk mengetahui hasil belajar siswa

- Koordinasi dengan guru PKn yang bertindak sebagai observer dalam proses pembelajaran

- Menyiapkan bahan ajar

- Menyiapkan Perencanaan Pembelajaran (RPP) yang dikembangkan berdasarkan pembelajaran kontekstual dengan pendekatan Authentic intruction learning.

- Menyiapkan soal tes beserta jawaban untuk mengetahui hasil belajar siswa

- Koordinasi dengan guru PKn yang bertindak sebagai observer dalam proses pembelajaran.

\section{Tahap Pelaksanaan:}

- Dilaksanakan satu kali pertemuan yaitu pada tanggal 6 mei, di kelas VIII4 dengan waktu yang tersedia 2x40 menit.

- Penyampaian materi secara klasikal yang menyangkut kemudian di lanjutkan dengan diskusi kelompok berdasarkan pembelajaran kontekstual dengan pendekatan Authentic Intruction Learning.

- Pada tahap presentase masingmasing kelompok menunjuk salah satu kelompoknya untuk menyampaikan hasil diskusinya dan semua anggota memiliki tanggung jawab atas hasil diskusinya.

- Melakukan tes hasil belajar siklus I dengan cara memberi 10 soal dalam bentuk pilihan ganda
- Dilaksanakan satu kali pertemuan yaitu pada tanggal 13 mei, di kelas VIII4 dengan waktu yang tersedia 2x40 menit.

Penyampaian materi secara klasikal yang menyangkut kemudian di lanjutkan dengan diskusi kelompok berdasarkan pembelajaran kontekstual dengan pendekatan Authentic Intruction Learning.

- Melakukan tes hasil belajar siklus II dengan cara memberi 10 soal dalam bentuk pilihan ganda

\section{Siklus III}

- Menyiapkan bahan ajar

- Menyiapkan Perencanaan Pembelajaran (RPP) Dalam langkah-langkah pembelajaran didominasi oleh siswa, sedangkan guru hanya membantu siswa dalam proses diskusi, akan tetapi pengontrolan dilakukan lebih efektif. Sehingga siswa masih malu bertanya menjadi lebih aktif bertanya.

- Menyiapkan soal tes beserta jawaban untuk mengetahui hasil belajar siswa

- Koordinasi dengan guru PKn yang bertindak sebagai observer dalam proses pembelajaran

- Dilaksanakan satu kali pertemuan yaitu pada tanggal 20 mei, di kelas VIII4 dengan waktu yang tersedia 2x40 menit.

- Penyampaian materi secara klasikal yang menyangkut kemudian di lanjutkan dengan diskusi kelompok berdasarkan pembelajaran kontekstual dengan pendekatan Authentic Intruction Learning tentang materi pembelajaran kedaulatan rakyat.

- Setelah guru memberikan motivasi,umpan balik yang sesuai dengan tujuan pembelajaran.Guru menyiapkan bahan ajar, rencana pelaksanaan pembelajaran (RPP).

- Pada tahap presentase masingmasing kelompok menunjuk salah satu kelompoknya untuk menyampaikan hasil diskusinya dan semua anggota memiliki tanggung jawab atas hasil diskusinya.

- Melakukan tes hasil belajar siklus I dengan cara memberi 10 soal dalam bentuk pilihan ganda.

\section{Tahap observasi:}

- Banyak siswa yang ikut tes: 38 orang

- Banyaknya siswa yang tuntas: 22 orang

- Banyak siswa yang tidak tuntas: 16 orang

- Persentase ketsuntasan belajar siswa: $57,89 \%$

- Ketuntasan Klasik
Banyak siswa yang ikut tes: 38 orang

- Banyaknya siswa yang tuntas: 30 orang

- Banyak siswa yang tidak tuntas: 8 orang

Persentase ketsuntasan belajar siswa: $57,89 \%$

- Ketuntasan Klasik
- Banyak siswa yang ikut tes: 38 orang

- Banyaknya siswa yang tuntas: 38 orang

- Banyak siswa yang tidak tuntas: o orang

- Persentase ketsuntasan belajar siswa: $57,89 \%$

- Ketuntasan Klasik 
- $=\frac{22}{38} x 100 \%$

- $=57,89 \%$
- $=\frac{30}{38} x 100 \%$
- $\quad=78,94 \%$

$=\frac{38}{38} \times 100 \%$

- $\quad=100.00 \%$

\section{Tahap Refleksi:}

- Siswa kurang berani bertanya kepada guru maupun kepada temannya ketika masih belum mengerti. Hal ini disebabkan siswa merasa malu dan ditertawakan oleh temannya. Untuk mengatasi hal tersebut guru memberikan point tambahan kepada siswa yang berani bertanya ataupun mengeluarkan pendapat.

- Pada saat diskusi siswa kurang bisa menjawab pertanyaan temannya. Hal tersebut disebabkan siswa kurang siap dalam menjawab pertanyaan yang diajukan temannya. Untuk mengatasi hal tersebut guru memberikan motivasi kepada siswa untuk belajar dan mengusahakan bisa menjawab pertanyaan yang diajukan oleh temannya.

- Siswa kurang memperhatikan dan menghargai penjelasan dari temannya. Hal tersebut diatasi dengan mengarahkan dan menyuruh siswa yang lain untuk menjelaskan penjelasan temannya.

- Siswa kurang dalam menyimpulkan materi yang telah dipelajari. Untuk mengatasinya guru harus lebih efektif lagi dalam menarik kesimpulan selanjutnya
- Hal ini menunjukkan bahwa tindakan pada siklus I siswa yang mendapat nilai 70 ke atas sebanyak 28 orang dengan nilai rata-rata $68.68 \%$ serta ketuntasan belajar siswa 78.94\%.Dengan demikian menunjukan bahwa pada siklus II ini belum berhasil memenuhi standar minimal harus mencapai $85 \%$. Maka perlu di adakan perbaikan
- Berdasarkan hasil tindakan siklus kedua menunjukkan bahwa ketuntasan pembelajaran baik dari aktivitas kegiatan guru dalam implementasi rancangan pembelajaran Contextual Teaching and Learning maupun tingkat pemahaman dan ketuntasan belajar siswa sudah memenuhi standar yang telah ditentukan oleh peneliti. Namun masih ada siswa yang berada dibawah target yang telah ditentukan oleh peneliti, selain itu perlu juga adanya bimbingan belajar secara terusmenerus oleh guru bidang studinya jika penelitian ini telah selesai dilakukan 


\section{Pembahasan}

Penerapan pembelajaran Authentic Intruction Learning ini dapat meningkatkan pemahaman siswa ini dilakukan selama 1 bulan dengan 4 kali pertemuan yang disain dalam penelitian tindakan kelas. Berdasarkan hasil evaluasi pemahaman siswa pada setiap siklus mengalami peningkatan. Berikut ini presentase test pemahaman siswa setiap siklus.

\section{Tabel 2}

Data pemahaman belajar siswa pada siklus I, II,dan III

\begin{tabular}{lccc}
\hline \multicolumn{1}{c}{ Hasil } & Siklus I & Siklus II & $\begin{array}{c}\text { Siklus } \\
\text { III }\end{array}$ \\
\hline Rata-Rata & 65,52 & 72.36 & 84.47 \\
Ketuntasan \% & $57,89 \%$ & $78,94 \%$ & $100 \%$ \\
\hline
\end{tabular}

Meningkatnya hasil pemahaman tersebut disebabkan oleh antusias siswa dalam proses pembelajaran dan diimbangi usaha guru dalam menciptakan pembelajaran yang efektif. Hal senada sesuai teori belajar[16] bahwa semakin tinggi aktivitas belajar siswa maka semakin tinggi pula peluang jasanya pembelajaran, sehingga guru dituntut untuk mampu meningkatkan aktivitas siswa dalam melaksanakan pembelajaran. Demikian juga lainnya menjelaskan bahwa semakin tinggi menggunakan variasi model pembelajaran semakin tinggi pula dampak hasil belajar siswa [17].

Adanya peningkatan tersebut dipengaruh oleh adanya upaya perbaikan tindakan yang dilakukan oleh guru. Adapun tindakan yang dilakukan tersebut antara lain: (1) Guru memberikan pertanyaan kepada siswa atau memberikan kesempatan untuk bertanya maupun menjawab pertanyaan dari guru maupun dari temannya sehingga terjadi komunikasi timbal balik antara guru dan siswa, (2) Guru mengarahkan siswa untuk bisa menghargai dan memperhatikan penjelasan temannya, (3) Guru memotivasi siswa yang pasif menggunakan kartunya. (4) Guru juga memberikan penghargaan kepada siswa dan kelompok terbaik.

Motivasi yang diberikan kepada siswa dengan memberikan reward atau hadiah dan pujian kepada siswa dengan nilai tertinggi. Hadiah yang diberikan guru memang tidak seberapa hanya sebuah kotak pensil tetapi hal tersebut dapat meningkatkan hasil belajarnya, sebagaimana diungkapkan oleh para tokoh aliran behavioris diantaranya Thorndike, Waston, Skinner dan Clark Hull, yang mengatakan bahwa belajar terjadi bila perubahan dalam bentuk tingkah laku dapat diamati sebagai akibat dari adanya stimulus dan respon. Jika seorang menunjukkan perilaku belajar yang baik akan mendapatkan hadiah dan kepuasaan. Siswa yang telah mendapatkan hadiah sebagai penguatan akan semakin meningkatkan kualitas perilaku belajarnya. Sebaliknya jika siswa menunjukkan perilaku belajar yang tidak baik maka akan mendapatkan hukuman. Demikian juga lainnya menjelaskan ada beberapa cara yang digunakan oleh seorang guru dalam menimbulkan motivasi belajar estetika siswa[18] yaitu memberikan penghargaan dan celaan, persaingan atau kompetisi, memberikan hadiah dan hukuman dan pemberitahuan tentang kemajuan belajar siswa.

Pembelajaran berbasis masalah dikenal dengan nama lain seperti pembelajaran proyek (project-based learning), pendidikan berbasis pengalaman (experience based learning), pembelajaran otentik (authentic learning) dan pembelajaran berakar pada kehidupan nyata (anchored instruction). Peran guru dalam pembelajarn berbasis masalah adalah menyaji-kan masalah, mengajukan pertanyaan, dan memfasilitasi penyelidikan dan dialog. Peng-ajaran berbasis masalah tidak dapat dilaksana-kan jika guru tidak mengembangkan ling-kungan kelas yang memungkinkan terjadinya pertukaran ide secara terbuka. Intinya, siswa dihadapkan situasi masalah yang otentik dan bermakna yang menantang siswa untuk memecahkannya [19].

Secara keseluruhan tindakan dari siklus I, siklus II ke siklus III menunjukkan perbaikan dan peningkatan hasil belajar siswa menunjukkan bahwa penerapan pembelajaran Authentic Intruction Learning menyebabkan suasana kelas lebih hidup dengan partisipasi aktif siswa dalam kegiatan pembelajaran, sehingga pembelajaran menjadi lebih aktif. Dengan demikian bahwa pembelajaran Authentic Intruction Learning merupakan konsep pembelajaran yang melibatkan siswa secara langsung untuk lebih aktif dalam proses pembelajaran dan dapat meningkatkan aktivitas dan pemahaman siswa.

\section{SIMPULAN DAN SARAN}

Penerapan pembelajaran Authentic Intruction Learning mampu meningkatkan pemahaman belajar siswa pada mata pelajaran Pendidikan Kewarganegaraan. Hal ini terlihat pada siklus I nilai rata-rata dari 38 siswa adalah 65,52 dengan persentase ketuntasan belajar adalah $57,89 \%$, kemudian pada siklus II nilai rata-rata dari 38 siswa adalah 72.36 dengan persentase ketuntasan belajarnya adalah 78,94\%, kemudian pada siklus III diperoleh nilai rata-rata dari 38 siswa adalah 84,47 dengan presentase ketuntasan belajar adalah $100 \%$.

Dengan demikian hasil penelitian tersebut sangat untuk meningkatkan pemahaman pembelajaran pendidikan kewarganegaraan untuk disarankan kepada pemerintah, sekolah dan guru untuk membuat kebijakan agar pembelajaran Authentic Intruction Learning mampu meningkatkan pemahaman belajar siswa. Selain itu peneliti berikut dapat mengkaji pada variabel lainnya. 


\section{UCAPAN TERIMA KASIH}

Penulis mengucapkan terima kasih kepada semua pihak yang telah membantu menyelesaiakan penelitian ini yang senantiasa memberikan data dan informasi kepada penulis sehingga penelitian ini selesai dengan baik.

\section{DAFTAR RUJUKAN}

[1] C. C. Johnson, D. Zhang, and J. B. Kahle, "Effective science instruction: Impact on high-stakes assessment performance," RMLE Online, vol. 35, no. 9, pp. 1-14, 2012.

[2] L. J. Splitter, "Authenticity and constructivism in education," Stud. Philos. Educ., vol. 28, no. 2, pp. 135151, 2009.

[3] B. Preus, "Authentic instruction for 21st century learning: Higher order thinking in an inclusive school," Am. Second. Educ., pp. 59-79, 2012.

[4] L. Garrett, L. Huang, and M. C. Charleton, "A Framework for Authenticity in the Mathematics and Statistics Classroom.," Math. Educ., vol. 25, no. 1, pp. 32-55, 2016.

[5] B. C. Rubin, J. Ayala, and M. Zaal, "Authenticity, aims and authority: Navigating youth participatory action research in the classroom," Curric. Inq., vol. 47, no. 2, pp. 175-194, 2017.

[6] L. Nikitina, "Creating an authentic learning environment in the foreign language classroom," Int. J. Instr., vol. 4, no. 1, 2011.

[7] R. Wulandari, "Penerapan Model Pembelajaran Contextual Teaching And Learning Tipe Authentic Instruction Untuk Meningkatkan Hasil Belajar Murid Pada Mata Pelajaran Ilmu Pengetahuan Alam Kelas V Sekolah Dasar Negeri 134 Kecamatan Senapelan Pekanbaru." Universitas Islam Negeri Sultan Syarif Kasim Riau, 2014.

[8] M. I. Abdi, "Contextual Teaching and Learning (CTL) dalam Pembelajaran PAI," Din. Ilmu, vol. 11, no. 1, 2011.

[9] R. B. Iucu and E. Marin, "Authentic learning in adult education," Procedia-Social Behav. Sci., vol. 142, pp. 410-415, 2014.

[10] T. C. Hiang, Y. M. Chan, G. P. Hong, and S. A. M. M. Ismail, "Incorporating The Authentic Learning Approach In An Adult Learners'classroom At A Public University In Malaysia," Int. J. Arts Sci., vol. 5, no. 3, p. 281, 2012.

[11] S. von Bormann, K. Turner, T. Boonprasith, D. Dhammakul, and W. Khamwong, "Effects Of The English Course Using An Authentic Learning Approach On Competency And Satisfaction Of Nursing Students," in PROCEEDINGS OF INTERNATIONAL CONFERENCE ON ALLIED HEALTH SCIENCES, 2012, p. 10.

[12] M. Marlina, S. Utaya, and L. Yuliati, "Pengaruh Authentic Problem Based Learning (aPBL) Terhadap Penguasaan Konsep Ipa Siswa Kelas Iv Sekolah Dasar," J. Pendidik. Teor. Penelitian, dan Pengemb., vol. 2, no. 11, pp. 1509-1514, 2017.

[13] K. Kartono, Pemimpin dan kepemimpinan. Rajawali Pers, 2018.

[14] N. Sudjana, Belajar dan Faktor-faktor yang Mempengaruhinya. 2010.

[15] M. I. Hasibuan, "Model Pembelajaran CTL (Contextual Teaching and Learning)," Logaritma J. Ilmu-ilmu Pendidik. dan Sains, vol. 2, no. 1, 2014.

[16] A. Sakban and W. Wahyudin, "Penerapan Model Cooperative Learning Tipe Numbered Head Together (NHT) Terhadap Hasil Belajar Pendidikan Pancasila dan Kewarganegaraan Sekolah Menengah Pertama," Civ. Pendidikan-Penelitian-Pengabdian Pendidik. Pancasila dan Kewarganegaraan, pp. 18-24, 2019.
[17] E. Prayitno, "Motivasi dalam belajar," Jakarta: Depdikbud, 1989.

[18] H. Sofyan and K. Komariah, "Pembelajaran problem based learning dalam implementasi kurikulum 2013 Di SMK," J. Pendidik. Vokasi, vol. 6, no. 3, pp. 260-271, 2016.

[19] F. Newman and G. Wehlage, "Restructuring for authentic student achievement," Authentic Achiev. Restruct. Sch. Intellect. Qual., pp. 286-301, 1996. 